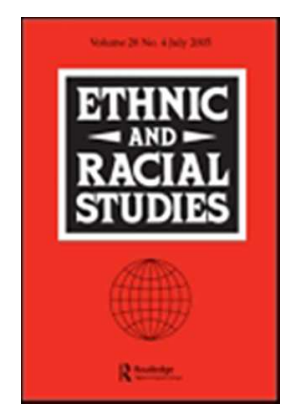

\title{
The Hieroglyphics of the Border: Racial Stigma in Neoliberal Europe
}

\begin{tabular}{|r|l|}
\hline Journal: & Ethnic and Racial Studies \\
\hline Manuscript ID & RERS-2016-0552.R2 \\
\hline Manuscript Type: & S.I. RACE AND CRISIS \\
\hline Keywords: & Racism, migrants, refugees, Czech Republic, Stigma, borders \\
\hline \multicolumn{2}{|l}{} \\
\hline
\end{tabular}

SCHOLARONE ${ }^{\text {IN }}$

Manuscripts

URL: http://mc.manuscriptcentral.com/rers ethnic@surrey.ac.uk 


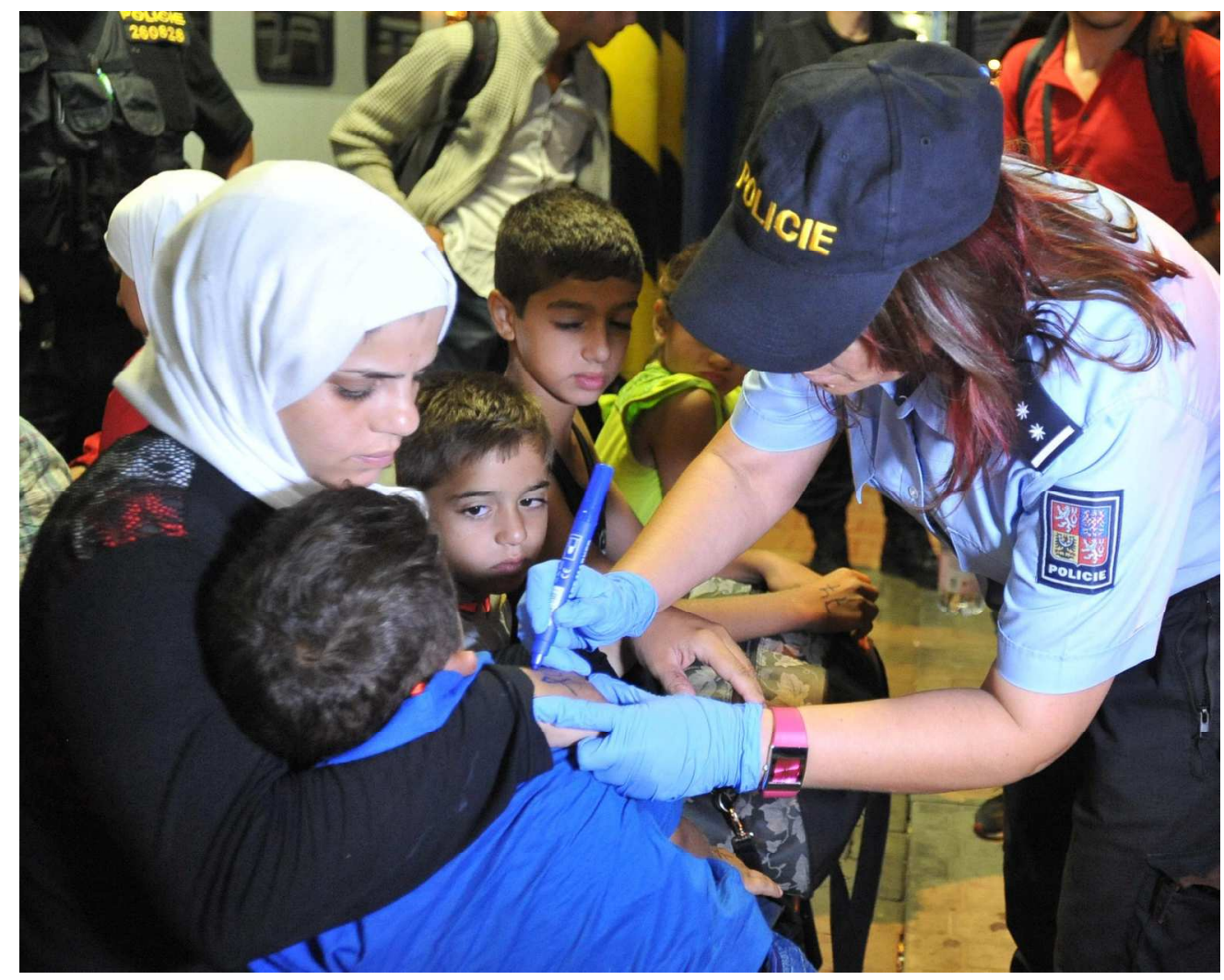

Břeclav, South Moravia, Czech Republic, 1 September 2015 Igor Zehl/Associated Press (C)TK / Alamy Stock Photo, copyright permission obtained.

$381 \times 305 \mathrm{~mm}(150 \times 150$ DPI $)$ 


\title{
TITLE: The Hieroglyphics of the Border: Racial Stigma in Neoliberal Europe
}

\author{
AUTHOR: Imogen Tyler, Sociology Department, Lancaster University, \\ Lancaster, UK
}

\section{ABSTRACT}

In the summer of 2015, 1.5 million refugees arrived at Europe's borders. This article examines how and why this humanitarian crisis was transformed into a 'racist crisis'. It begins by recounting a highly publicised event in the Czech Republic which saw police forcibly removing hundreds of people from trains at midnight in the border town of Břeclav, before inking numbers on their arms and transporting them to detention centres. Thinking with this scene, the article develops the conceptual framework of 'racial stigma' to capture some of the multiple practices that characterize border regimes in Contemporary Europe. Racism, it argues, is the stigma machine of sovereign power in neoliberal Europe. The article concludes with some reflections on how Europe's current 'racist crisis' reanimates both historical spectres of race and spectral geographies of racism.

ARTICLE HISTORY Received 21 November 2016 Accepted 12 July 2017

KEYWORDS Racism, migrants, refugees, Czech Republic, stigma, borders 


\section{The Hieroglyphics of the Border: Racial Stigma in Neoliberal Europe}

Swim harder, darkie. See whether you can reach Europe (in Čulík 2015).

During 2015, an unprecedented 1.3 million people applied for asylum in the 28 member states of the European Union, Norway and Switzerland. This was "nearly double the previous high-water mark of approximately 700,000 [asylum] applications in 1992, after the fall of the Iron Curtain and the collapse of the Soviet Union" (Connor, 2016). Those seeking protection in Europe were largely fleeing wars, conflicts and political oppression in Syria (over 50 per cent), Iraq, Afghanistan and Eritrea. Some arrived via Balkan land routes, but these borders were soon blocked and the vast majority made treacherous Mediterranean Sea-crossings (from Turkey and Libya). An estimated 3771 people drowned in the Mediterranean in 2015 alone and in the summer of 2015, newspapers and news websites across the world were filled with photographs of drowned children and people desperately paddling towards shore on overloaded dinghies. In response to the growing humanitarian crisis at Europe's border, the German Office for Migration and Refugees announced on the social media site Twitter on 25 August 2015 that they were "no longer enforcing \#Dublin procedures for Syrian citizens. "i What this meant for Syrian refugees on the ground was that if they could navigate a route to Germany, they would be guaranteed at least temporary leave to remain. This triggered "a million-man march through Europe" as hundreds of thousands of people caught in dire conditions at camps and transit zones across Europe's southern borders made their way north by foot, car, bus and train (Foster 2016). It was amidst this intensifying human and political drama that shortly after midnight on 1 September 2015, two trains drew to a halt in Břeclav, a town in the Czech Republic, close to the border with Austria and Slovakia.

\section{Scene One: Břeclav Railway Station, Czech Republic}

At Midnight on 1 September 2015, a squad of Czech Alien Police boarded two trains in Břeclav and forcibly removed 214 people (115 men, 38 women and 61 children). The first train had arrived from Vienna shortly before midnight, the second shortly after midnight from Budapest, both bound for Germany. Czech government officials described the passengers removed from these two trains as "214 illegal migrants." The vast majority, over 90 per cent, were refugees from Syria and were just hours away from their German destination when the trains were intercepted by police, who moved through carriages checking people's documents. After escorting people from the trains, some in 
handcuffs, the police assembled people on the platforms and proceeded to use indelible pens to ink numbers on their arms and wrists. Kateřina Rendlová, a spokeswoman for the Czech Alien Police stated that the inking of refugees was a means of keeping a record of family members: "We also write the code of the train they have arrived on so that we know which country we should return them to within the readmission system", adding, "we used to put the numbers on a piece of paper but they kept throwing them away" (Flemr 2015). The refugees were then packed onto buses destined for temporary camps in local school gymnasiums in south Moravia, where officials said they would be processed, before being transferred to remote rural detention centres.

[insert figure 1]

Events at Břeclav were captured by Czech News Agency photojournalist, Igor Zehl, and were posted on the associated press website. One photograph in particular caught the attention of international news editors: an image of a small child sitting on his mother's lap, his face folded into her body, while a Czech policewoman wearing blue plastic gloves wrote numbers on his arm (figure 1). This image was printed in newspapers, published on news websites and shared across social media platforms around the world, provoking an international outcry from human rights organisations for the disturbing associations it elicited with the badging and tattooing of Jews during the Second-World War. As Ruth Dureghello, a Jewish community president in Rome, explained:

It is an image we cannot bear, which recalls to mind the procedure at the entrance of Nazi extermination camps, when millions of men, women and children were marked with a number, like animals, and they were sent to die (AFP \& JTA 2015).

These allusions to the Nazi holocaust were not lost on far-right activists. Adam Bartoš, the leader of the fascistic Czech party, the National Democracy Movement used Facebook to call for the Breclav “intruders" to "be concentrated in Theresienstadt" (2015a). . These views, as Jan Čulík (2017) has extensively detailed, were symptomatic of rising populist anti-refugee sentiments in the Czech public sphere. Indeed, it was not extremist minorities but rather the Czech President, Milos Zeman, who was the "major catalyst" for the crafting of "mendacious anti-refugee narrative[s]" (Čulík 2017). Zeman warned the Czech public that refugees where 'Muslim invaders' who might bring infectious diseases into the nation and could harbour "sleeper cells" of Islamic terrorists (Schultheis 2015). The fear this generated was apparent in local responses to the detention of refugees in Břeclav. On 8 September, 350 people turned up to a meeting convened by the police, the Mayor and representatives from the Czech Government Ministry of the Interior to reassure the local population. Officials offered reassurances that refugees would be segregated from any contact with 
local people. "The conversation", reported a local journalist, "was refined and quiet. Only occasionally did the audience shout out statements such as 'It's too late. Europe has turned black'" (Hrabal 2015, my translation, my emphasis).

\section{Introduction}

This article unfolds from Břeclav, "digging into" this scene in order to better understand "the rush of past racial 'debris'” it provoked (Amin 2010, 3, 6). Historical figures of 'race' and latent forms of 'race thinking' haunt Europe. Indeed, racism draws its "narrative energies" from existing grids of associations, from "semantic and iconic folds" that are deeply etched in the collective memories of people and places (Spillers 2003, 210). In this article, I explore how different genealogies of racism converged in responses to the 'refugee crisis' as "migrants became a focus point" for public concerns "about European values and their crisis" (Gagyi et. al. 2016). In what follows, I first briefly outline the political and economic context in which the Czech response to the 'refugee crisis' emerged, and the histories of racism in the region which enabled this humanitarian crisis to be recast as a 'racial crisis'. I then consider the ways in which responses to the inking of refugees at Breclav gave rise to 'epidemics of racial stigma' in the wider context of news and social media responses. The article then examines the abject conditions endured by refugees in Czech immigration detention centres. It argues that the stigmatization of refugees (both literally and symbolically) legitimates illegal practices of dehumanization and degradation in detention. The article concludes with some reflections on how the 'refugee crisis' animates historical spectres of racism. The afterword invites the reader to confront these ghosts by returning once more to Břeclav train station. The main argument of this article is that racism is a primary technology of statecraft in contemporary Europe. Whether performed with razor wire or crafted through words, borders are "racial assemblages" through which humanity is classified and disciplined into "humans, not-quite-humans, and nonhumans" (Weheliye 2014, 8). Racism is not only an accessory of border control; rather, in a more fundamental and material sense, racism makes borders.

\section{Context: The Czech Republic and the Visegrád states}

To begin, it is necessary to provide some context for those unfamiliar with the political situation in Eastern Europe. The Czech Republic is a nation of 10.5 million which joined the European Union (EU) in 2004 as part of a group of former communist states, Hungary, Poland, and Slovakia, which are known collectively as the Visegrád group. From the early 1990s the Visegrád states were transitioned from Soviet-style command economies, to neoliberal market economies. This process involved the 
implementation of the 1993 Copenhagen criteria, a policy package involving rapid privatization of state-owned infrastructure and assets and the liberalization of labour and financial markets (Hamm, King \& Stuckler 2012). While the availability of cheap credit initially cushioned the impact of neoliberal reforms, this 'shock treatment' injected economic inequality into the region: wage levels collapsed, workers' rights and welfare provisions were eroded, public services and infrastructures privatized (Blanden 2016). As a consequence, and particularly in the wake of the 2008 North Atlantic Financial crisis, there has been public disillusionment across the Visegrád states with the "so-called 'freedom' and capitalism" promised by EU membership (Biray 2015). This disenchantment has seen an electoral shift away from "democratic parties which embraced neoliberalism and austerity" to nationalist right wing parties (Blanden 2016).

As Jodi Dean argues, the inequalities and insecurities introduced by "globalized neoliberal capitalism" requires the simultaneous crafting of "racist, nationalist ethnocentrism" (Dean 2012, 40). On cue, as the humanitarian crisis at Europe's borders deepened, Visegrád politicians harnessed the animosities generated by growing economic inequalities in the region to nationalist fantasies of 'ethnic security' through 'border security'. As Zeman put in his 2015 Christmas address to the nation: "I am profoundly convinced that we are facing an organized invasion and not a spontaneous movement of refugees" (Zeman 2015). Visegrád politicians began to craft a geopolitical role for the region as a buffer zone against which (Western) Europe could be protected against this 'incursion'. Indeed, 2015 saw a rush of fence-building on Eastern borders, the opening of new camps to detain migrants, the formation by neo-nazis of 'human walls' against refugees on state borders and the formation of armed citizen militia groups, such as Hungary's state-funded "border hunters" and a 2,500-strong Czech vigilante border militia. 
In the Czech Republic, a populist narrative emerged which, animating histories of German and Communist occupation, imagined the Czech people in an existential struggle against invading 'foreign hordes'. This struggle was explicitly framed as a 'race war'. For example, a news headline on $3^{\text {rd }}$ September, 2015, quoted Czech Sociologist, Petr Hampl, stating, "We have the right to deal with the refugees as though they were aggressors. The traitors of the Czech nation are helping them to exterminate us like the whites have exterminated the Red Indians" (Čulík 2017). Explicit in these kinds of racial narratives was the idea that liberal Western European political leaders failed to understand the 'genocidal' consequences of granting refuge to Middle Eastern, African and/or Muslim refugees. For example, an editorial in the Czech broadsheet newspaper Lidové Noviny, penned by 'expert ethnologist' Mnislav Zelený-Atapana and titled, "Is a genocide against whites next for Europe?", argued that: "Mrs Merkel and those like her are basically undertaking an artificial mixing of the races in which the white race will be gradually liquidated and we Europeans will become black or brown. This is a genocide against white people" (Zelený-Atapana 2016). These ethnonationalist sentiments spilled onto the streets: On 12 September 2015 thousands gathered in Prague to protest against refugee arrivals, one of many such demonstrations across the country and wider region that year. Video footage of this protest captures a carnival atmosphere with young people, and families with children, carrying Czech flags and holding up banners carrying the demands, 'Send them back!' and 'Protect the borders'. Many wore T-Shirts and face paint adorned with anti-Islamic and anti-refugee slogans, and crowds chanted in unison 'Fuck Off, Islam'.

It is important to note that Visegrád states are transition rather than destination countries for refugees. For example, in 2015 the Czech Republic granted refugee protection to a mere 71 people, out of a total of only 1,525 asylum applications. Indeed, these are states that habitually record negative net migration rates, as young people seeking higher wages migrate West. National policies in the region are designed to deter refugees and migrant workers, despite growing labour shortages. The small numbers of refugees straying onto Czech territory in the summer of 2015 were seeking only to cross the border. In practical terms, refugees and migrants are unlikely to be able to speak Czech or to have family, friends or other contacts to induce them to remain. What this tells us is that the inking and detention of the refugees at Břeclav was orchestrated political theatre. The refusal to let refugees continue unmolested on their journeys was an opportunity to demonstrate control over national borders. In particular, the timing of the detention of the refugees at Břeclav was designed to add weight to a Visegrád-wide negotiating position on a proposed EU quota system that would require states to accept an agreed number of Syrian refugees. A matter of hours after the detention of refugees at Břeclav, the Czech Interior Minister stated to journalists that he was interested in 
negotiating a "simplified procedure" with Berlin, which might allow refugees to travel unmolested across Czech territory on the understanding that any quota scheme would be "unacceptable to the Czech government" (2015b).

Neighbouring Hungary, which under the leadership of Viktor Orbán has led the war against refugees in the region, had considerably more arrivals than the Czech Republic in 2015. On October 2nd 2016, the Hungarian Government held a referendum on the EU quota system to share 'the burden' of Syrian refugee settlement. ${ }^{\text {iii }}$ What was most significant about this referendum was the "gigantic wave of racist state propaganda" that preceded it, which ranged "from giant billboards to new elementary school textbooks, from the internet to hundreds of thousands of personal phone calls civil servants were forced to make to mobilize for the 'no' vote" (Tamás 2016).This campaign "cost Hungarian taxpayers the equivalent of over $\$ 18$ million - or approximately $\$ 13,500$ per asylum seeker Hungary has been asked to take" (Gall 2016). It also marked state-funded racism on a scale not witnessed in Europe since the Nazi propaganda of the 1930s and 1940s. This was, in short, an eruption of state racism which liberal democracies further West had long sought "to freeze in the past" (Lentin 2016).

\section{Genealogies of Racism in Europe}

As Magdalena Nowicka argues "Eastern Europe remains a blind spot in theorizing racism in Europe" (Nowicka 2017). Under communist rule, while racism was widely practiced against racialized minorities, notably the Roma, racism didn't officially exist. Further, even though the worst atrocities of WWII took place on Nazi-occupied Central and Eastern European soil (often with the collaboration of local populations), there was no acknowledgement of historical state racisms. Even while the material remnants of a more multicultural past were 'hidden in plain sight', for example in formerly Jewish neighbourhoods and empty Synagogues, neither the genocides that took place during the Nazi occupation, nor the racial classification of Eastern Europeans as 'Slavs', nor the expulsion of German-speaking citizens after the war, was understood through the lens of racism. ${ }^{\text {iv }}$ While the absence of racial genocide from official histories of Eastern European states has been partially revised since the fall of 'the Iron Curtain', this process has been complicated by the ways in which ethnic forms of nationalism became associated with freedom from communist totalitarianism. Furthermore, it is not only that state racism has been historically repressed, but that racism per se as a topic of debate and concern, continues to be marginalised within the Visegrád public sphere, including academic scholarship. As Nowicka notes in the Polish context, "the popular opinion, 
common also among Polish scholars [is] that 'the racial problem has never existed in Poland'" (Nowicka 2017, 4). What is now faced is a situation in which racism has emerged "starkly into the open", but is imagined as a 'new' problem which originates from 'outside' (Fella \& Ruzza 2013). In short, racism is imagined as a problem imported from the west. As Zelený-Atapana puts it:

\begin{abstract}
They started in the distant past colonialist division of the world and after WWII began to reap the rotten fruit as they opened borders to people of former colonies. We, however, not participate in [colonialism] and therefore we have no moral obligation to accept refugees (Zelený-Atapana 2016).
\end{abstract}

It is important to note also that 'race' is still popularly understood in Eastern Europe through the lens of scientific racism (Nowicka 2017). This was evident in 'expert' responses to 'the refugee crisis', where racist views about refugees were expressed not only in terms of religious and cultural differences (for example as Islamophobia), but also in terms of 'biological differences'. The persistence of these 'older' forms of race-thinking trouble liberal understandings of 'European racism', which have been theorised almost exclusively from the perspective of 'the West'.

In Western Europe 'scientific' theories of race have been publicly discredited since WWII and there has been official acknowledgment of state racism through the memorialisation of (some) past genocides, albeit primarily Nazi-era atrocities that took place on European soil. However, this commemoration of 'racist crimes' occludes "the foundational relationship between the liberal political project and the racial-colonial domination within and despite which it developed" (Lentin 2017). Further, as Lentin (2016) argues, if 'real racism' is a thing of the past, the endurance of racism is imagined, and legislated against in Western Europe, as the aberrant behaviour of deviant individual racists. In the process, actually existing forms of institutional and state racism, including the ongoing exclusion of racialized citizens from the full rights and protections of citizenship, is occluded.

The convergence of postcommunist and liberal regimes of racism in governmental responses to the 'refugee crisis' was frequently imagined in liberal Western European commentary as a conflict between 'backward' Eastern European racism and the "superior moral stance of humanitarianism" (Gagyi et. al. 2016). By 'freezing' racism geographically in the East, state racism against refugees and other racialized minorities was orientalised as a symptom of under-development, a sign of the distance "they" must travel "to become liberal, humanitarian and modern Europeans" (Gagyi et. al. 
2016). This article doesn't seek to contribute to the stigmatisation of Eastern Europe as 'more racist' than 'the West', or diminish the central role of Western European powers in enabling deaths at the borders. It is, however, interested in what we might learn from the conjunction of these different genealogies of racism. Not least, in terms of what these different registers of racism might teach us about the dramatic blossoming of neofascist politics in Western Europe in the same period. For it is not only right-wing Visegrád politicians who have sought to craft and mobilise populist racisms as a means to make political capital 'at home'. This was evident in the UK Brexit campaign in 2016, where the two key themes of the leave campaign, namely "that immigration is unravelling" the nation and "anything foreign, except investment, is abhorrent" not only granted "a fillip to popular racism" but allowed "fully-fledged state racism" to emerge (Sivanandan, 2016). Indeed, while Hungary undertook a state-sponsored propaganda campaign against migrants in October 2016, the far-right United Kingdom Independence party used almost identical tactics and messages in its campaign to leave the EU. One of the most notorious posters in this campaign, titled "Breaking Point", and subtitled "We must break free of the EU and take back control of our borders", employed a photograph of refugees crossing the Croatia-Slovenia border in 2015 as 'evidence' that 'white' Europe was being 'invaded' by brown migrants.

\section{Penal Stigma}

people no more fasten the stigma of race upon themselves than cattle sear the brand into their own flesh (Fields \& Fields 2012, 102).

This article emerges out of a larger research project which draws on the long penal history of stigma, including material practices of penal tattooing, branding and badging and contemporary forms of symbolic violence, to reconceptualise stigma as a form of political power (Tyler forthcoming). Penal practices of marking the body are not only historically familiar forms of dehumanization, but also describe the original meaning of the word stigma. 'Stigma' ( $\sigma i(\gamma \mu \alpha)$ was a common Greek noun meaning 'a mark, dot, puncture', or 'a sign', from the verb otił $\omega$ ('to puncture'). In Ancient Greece, and in the Roman Empire, the word stigma was used to denote marks on the skin made by tattooing, which then, as now, involved the use of needles and ink. A stigma was a tattoo acquired as a punishment. To be stigmatized was to have a crime written into your flesh. Common stigmas included 'Thief!' or 'Stop me, I'm a runaway', tattooed across the face. A stigma might also record a specific sentence, such as deportation from the city-state for a period of forced exile and a sentence to a labour camp (Jones 1987; Gustafson 2000). These humiliating penalties were reserved for noncitizens, slaves and other resident aliens. Indeed, stigmatization was sometimes employed en masse 
to generate new sources of slave labour for the vast economies and infrastructures of Empire through the tattooing of captured enemy soldiers during border skirmishes and expropriation of enemy territory. As an ink tattoo was almost impossible to remove and often difficult to conceal, being stigmatized curtailed your mobility, making both everyday movements through public spaces and journeys across borders treacherous.

The word stigma retains traces of this original meaning. The Oxford English Dictionary defines stigma as 'a sign of severe censure or condemnation... impressed on a person' (OED 2014, my emphasis). However, in contemporary usage stigma is generally understood as the state of "disgrace itself", rather than the violent acts of inscription, badging, marking or tattooing that this penal genealogy suggests (Goffman 1986, 11). Since the mid-20th century, we have become accustomed to thinking about stigma as a problem of social norms, which can be challenged and alleviated through compassion and education. As I detail at length in forthcoming work, this modern usage erases continuities between ancient and contemporary practices of penal stigmatization. In actuality, penal practices of stigmatisation continued to be deployed over many centuries by European powers as terrorizing governmental technologies, from colonial practices of badging, tattooing and branding subjected populations overseas, through to the badging of the poor 'at home'. In uncoupling the meaning of stigma from this penal history, what we lose sight of is stigmacraft; the mechanisms through which stigma is produced, the processes through which it becomes attached to bodies, by whom, and for what purpose. Holding to a reading of stigma as a material practice of dehumanization is also suggestive of how and why the penal tattoo became intertwined with the modern history of racism. As Stuart Hall argues, race is a badge, a political practice of classification which is inscribed in the body (Hall 1997). This history of racial stigma can be illustrated through a few brief but resonant $20^{\text {th }}$-century historical examples.

\section{The Badge of Race}

German South-West Africa, modern-day Namibia, was a colony of the German Empire from 1884 until 1915. In areas under German control, all Africans over the age of 8 had to wear metal passes around their necks, which were embossed with the imperial crown, the magisterial district, and a number. As in Ancient Greece, this badging was a form of stigmatization that both humiliated colonial subjects, and allowed colonialists better control over the slave labour force. When people resisted this badging, for example by discarding their tags during escape attempts, a system of ink tattooing was proposed (Olusoga \& Erichsen 2010; Schaller 2013). Uprisings by the Herero against the colonial administration, led in 1904 to the adoption of an extermination policy against the Herero 
and Nama people in the region. What followed was described by then commander of German forces in South West Africa, Colonial General Lothar Von Trotha, as "a racial war" (Bridgeman \& Worley $2004,27)$. By 1906, the German colonists had murdered 65,000 Herero people out of a total population of 80,000 . Those who surrendered were branded with the letters "GH", for "Gefangene Herero" (imprisoned Herero), before being dispersed as slave labour on the farms of German settlers (Bridgeman \& Worley 2004, 30). Alongside the use of penal tattoos, this genocide saw the development of concentration camps in the region and the arrival of German scientists to conduct genetic experiments on the population to evidence the emerging 'racial sciences'.

These colonial applications of penal stigma as "race branding" (Sarkin-Hughes 2010, 27) were developed when, as Frantz Fanon puts it, "Nazism transformed the whole of Europe into a veritable colony" (Fanon 2005, 27). The establishment and expansion of the Nazi Empire in Eastern Europe involved the creation of a vast, bureaucratic stigma machine for the classification of 'racial enemies' (i.e. Jews, Gypsies and Slavs), 'asocial' elements (ie. the 'work-shy', criminals, sexual deviants), and 'useless eaters' (disabled people and 'the mentally ill'). The identification and classification of these 'aliens to the community' ('Germeninschafts-fremede') and 'pests harmful to the nation' ('Volksschalinge') was grounded in the racist practices of penal stigma developed in the German colonies. This included SS storm-troopers branding people with swastikas as a terrorising punishment (Gedye 1939, 503), and the introduction of laws forcing Jews to wear distinguishing badges, most often a yellow star, in public places. ${ }^{v}$ At labour and extermination camps an elaborate system of badging was developed to distinguish different classes of prisoners. Those designated for slave labour at camps, rather than immediate death, were often stamped with ink signs on their forehead, and labour numbers were also frequently inked on the skin. At the Auschwitz complex, stigmatization extended to the ink tattooing of serial numbers upon the arms of Jewish inmates selected for work. The Czech holocaust survivor Ruth Elias recalls that although she had survived near-starvation in the Jewish ghetto of Theresienstadt, it was only when she lined up to be tattooed at Auschwitz that she understood that she was longer considered a human being: 'The numbers on our forearms marked our depersonalization' (Elias 1999, 109-110).

This penal genealogy teaches us that stigma, like 'race', doesn't begin with a body "but with what that body was made to mean via the powerful grammars of capture" (Spillers 2003, 14). Further, it reveals how "the badge of race" has long been employed as an othering practice, a colouring device, to dehumanise slaves, colonial subjects, non-citizens, refugees and migrants (Hall 1997). While stigma is not always racializing, racism is its preeminent form. Stigma as racism is a "hieroglyphics of the flesh" (Spillers 2003, 21). This genealogy of penal stigma haunts Břeclav. 


\section{Transnational Racist Responses to Břeclav}

The British right-wing tabloid newspaper, The Daily Mail, hosts the most visited news website in the world, the MailOnline, which attracts a daily international readership of 12 million people. On September $2^{\text {nd }}$, the MailOnline featured Zehl's photograph of the child being inked by the Czech police in a news story titled 'Fury as Czech police write numbers on arms of migrants "like concentration camp prisoners"'. This story attracted 4000 readers' comments, extending over 23 pages, with comments from readers in the UK, Ireland, USA, Australia, New Zealand, Canada, Spain, and Singapore. Some readers responded - as invited by the use of scare quotes around 'concentration camp' in the title - with outrage at the suggestion of any analogy between the inking of refugees hands and concentration camp regimes, insisting, for example, that, "it's no different than having your hand stamped as you enter a night club". Many more suggested that more penal forms of stigmatization should be used to manage refugees at Europe's borders.

They should write the id numbers on the forehead instead!

You could inject them with an RFID tag, at least you could track them!"

Rubber stamp their foreheads instead!

They should be made to wear a yellow badge so that members of the public know who they are and know to stay well away from them.

With the numbers involved and the desperate deceit used by many of these people tattoos would be a more effective option. if they behave well give them a yellow star to wear too Pigs ears are clipped and tagged \#justsaying Just because the J E W S don't like it we must comply! Dig pits and machine gun the lot of them - Cheaper to use gas.

Well done Czech police... I'd brand them like cattle with a massive $M$ on their foreheads! Good idea - tattoo everyone with a barcode - easier to track They should all be fingerprinted, DNA samples taken and photographed before tattooing i11eg@1 on their fore head [sic]

While it is easy to dismiss or disregard these kinds of discussion threads, they are important archives of everyday stigmacraft in contemporary media cultures. Our task, as Les Back suggests, is to "develop a radical attentiveness' to racist speech, to understand the 'resonance and reach" of racist sentiments and conversations (Back 2008). The imagined anonymity of internet forums, and devices such the use of fabricated user names, offer users a license to break social taboos on racist speech, an opportunity to craft racism in extreme and virulent ways. Reading this discussion thread, it is 
evident there is enjoyment in provoking outrage, an intense pleasure in being racist with others in a community setting and by evading the censorship of forum moderators by, for example, placing spaces between letters in words like 'J E W S'. While some of the readers respond negatively to racist comments, for the majority the opportunity to be racist motivates their participation. As Kimberlé Crenshaw notes, "racism helps to create an illusion of unity through the oppositional force of a symbolic 'other'. The establishment of an Other creates a bond, a burgeoning common identity of all nonstigmatized parties" (Crenshaw 2010, 550).

The refugees arriving in Europe in the summer of 2015 are difficult to characterise in terms of a single religion, nationality or through racial colour lines. Perhaps to account for the difficulty in fixing a singular 'badge of race', the racism against refugees in the MailOnline thread conjures multiple figures and names: Muslims, Jews, Niggers, Arabs, and Terrorists morph into one another. Most notably, Nazi-era anti-Semitic practices are repurposed as anti-Muslim racism: "I'd brand them like cattle with a massive $M$ on their foreheads". The graphic character of the racism is striking, with many posts imagining different ways of stigmatising refugees. Signs and words are imagined impressed, branded, tattooed upon migrant bodies, stressing the relationship between racism, writing and wounding uncovered in the genealogy of penal stigma. Also notable are the many calls for the segregation and confinement of these 'waste populations' in concentration camps: "No one invited them to the Czech Republic!"; "Like roach infestation."; "Let the Germans set up some of their "special" camps in Poland for them."; We don't want them - go or be gone."

\section{Scene Two: Bělá-Jezová immigration detention centre, Czech Republic, 31 August 2015.}

Because the Czech Republic receives so few refugees, there are only three immigration detention centres in the Czech Republic. Coincidentally, on 31 August 2015, the very day that the refugees began the train journeys that ended at Břeclav, Anna Šabatová, the Czech Government's Public Defender of Rights, made an unannounced visit to Bělá-Jezová detention centre, a former Soviet Army Barracks. Šabatová's subsequent report offers important insights into the abject conditions faced by those refugees bussed from Břeclav on their arrival in detention. Indeed, the situation she describes at Bělá-Jezová is so disturbing that it triggered responses from the EU and from Zeid Ra'ad Al Hussein, the United Nations High Commissioner for Human Rights.

When she arrived at Bèlá-Jezová the chief of the Czech Alien Police at the centre tried to refuse Šabatová, and the four lawyers and two interpreters accompanying her, access, and attempted to remove the cameras they had brought to document conditions, despite that the unannounced 
inspection of prisons and detention centres is a regular part of the role of Public Defender of the Rights (Šabatová 2015, 4). Having gained access, Šabatová begins her inspection report on BěláJezová by noting that it had increased its capacity from 270 to 700 beds in a period of six months. During her visit on August 31st, there were 659 people, including 147 children, detained there. Šabatová describes how a constant "demonstration of force" is maintained throughout the centre by the "presence of uniformed private security guards, police officers, riot police unit and police dogs". The refugees relay their feelings "of utter humiliation." They tell Šabatová that some of the police officers "handled them roughly, or spit in front of them" and that "private security guards allegedly called them terrorists." Šabatová notes that people are frequently handcuffed and that many, including children, have insufficient clothing and shoes to keep warm and clean. Some of those she spoke to had no hot meals, but were surviving on rations of bread and cheese. Others had no direct access to toilets or running water, and had to rouse guards to be released from the rooms in which they were locked each time they needed the bathroom. Detainees described being given mattresses that were filthy and infested with lice. People also describe being subject to humiliating strip and body-cavity searches in front of families and children, ostensibly to make sure they are not hiding valuables; mobile phones, watches, shoelaces, belts, money, were confiscated on their arrival. The anxiety of being detained in these conditions was "intensified by the fact that they are unable to contact their relatives. Many have no way to report back home that they are alive, or to try and find a relative with whom they have lost contact" (Šabatová 2015, 7). Indeed, people don't know when they will be released and some don't even know which country they are in. Despite the claims of police at Břeclav, that people were being inked as a means of keeping families together, Šabatová discovers that family members are frequently separated in different detention centres (see also Ahmed-Čermáková 2015). Amidst this litany of details, she pauses to note in her report:

$$
\begin{aligned}
& \text { Simple description of the situation cannot fully convey the conditions in which these [people] } \\
& \text { were held, nor their psychological condition....They often come to believe they have been } \\
& \text { deprived of their humanity and treated as a "herd of animals" }(2015,29) \text {. }
\end{aligned}
$$

In the most shocking passage, Šabatová details her discovery of an annexe in a forest behind the main detention centre where people were living in tents and transport containers confined inside wire fencing:

The container units in the forest were 'discovered' only at the very end of the inspection visit. When [we] arrived on these premises, some of the detained foreign nationals raised 
banners such as: "We are refugees, not prisoners!" and "Help us, please". These people saw themselves as "caged animals" $(2015,13)$.

To add to their humiliation, people are charged for their stay: ordinarily imprisoned for 90 days at a cost of $€ 10$ per person, per day. These charges are 'levied' from confiscated cash and valuables. Many leave without any money left in their possession and are presented with a bill for their outstanding debts to the Czech Republic. This is a 'final deterrent' as it is illegal to claim asylum in the Czech Republic if you are financially indebted to the government. People are frequently released without prior warning, without even a map, directions or transport to the nearest train station: "destitute in front of the gate of the camp, in the middle of the forest" (Ahmed-Čermáková 2015). They are forced to seek assistance from Czech volunteers in order to continue on their journeys to Germany. Perhaps, as one activist wryly notes, on the very same train "from which police dragged them two months ago in Břeclav" (Ahmed-Čermáková 2015).

\section{Conclusion: Spectres of Fascism}

With regard to the Czech Republic, the United Nations concludes that "the violations of the human rights of migrants are neither isolated nor coincidental, but systematic: they appear to be an integral part of a policy by the Czech Government designed to deter migrants and refugees from entering the country or staying there" (United Nations 2015). This article has attempted to demonstrate the role of what I term 'racial stigma' in this process, the ways in which racial stigmatisation dehumanises people to the extent that it becomes possible to keep them caged and hidden in transport units. The penal practices of stigma I have described are also a reminder that it is impossible to imagine or think about 'race and crisis' in contemporary Europe without recourse to history. The tattooing of refugees, their removal from trains at night, the fearful and racist responses of local communities, the comments of MailOnline readers, with their advocacy of yellow stars, tattoos and gas chambers, the humiliating practices of strip-searching refugees, confiscating their valuables, and the abject and hidden conditions in which they are held, evoke ghosts of Europe's recent past. One argument of this article is that contemporary political struggles over borders pivot on "the seething presence" of these ghostly refugees - whether in calls from the far-right to detain the Břeclav refugees in Theresienstadt, or in claims that migrants are enacting 'white genocide', or in more liberal forms of memorialisation that seek to freeze 'real racism' in the past - or in 'the East' (Gordon 1997, 195). The thing about haunting, as Avery Gordon argues, is that it "alters the way we normally separate and sequence the past, the present and the future" allowing a "repressed or unresolved social violence" to make itself known (Gordon 2011). The processions of people arriving at the borders 
today, are caught at the same railway stations, waiting rooms, platforms and train tracks, and are even detained in some of the same camps and prisons, where refugees were gathered in the 30s and 40s. Reckoning with these ghosts is important because they have something valuable to tell us about the high stakes of Europe's current racist crisis. While conditions for industrial scale genocide of the 1940s don't currently exist in Europe, the ways in which we confront these spectres is a matter of life and death.

\section{Scene Three: Břeclav Train Station, 11 March 1938}

At midnight on 11 March 1938, a train carrying refugees was halted at Břeclav station. Drawing on eyewitness accounts, the British journalist George Gedye described how events unfolded that night. Earlier that evening Austrian Chancellor Kurt von Schuschnigg had resigned, surrendering Austria to annexation by the German Government. Jews, Communists, Catholics, Anti-Fascists and intellectuals scrambled to get on the last train from Vienna to Prague in order to escape before the German Army entered the city the following day. The train was supposed to leave at $11.15 \mathrm{pm}$, but by $8 \mathrm{pm}$ "thousands of people were pushing each other, squeezing themselves into the train while demanding to depart immediately" (Gedye 1939, 301). Before it was able to pull out of the station, Nazi Stormtroopers boarded the train "running through the carriages, armed with dog whips", looting and terrorizing passengers (301). Finally, the train departed. Then, 20 minutes into its journey, it was stopped in the middle of the countryside by the SS who proceeded to "go through the train with a fine-toothed comb" (301). Men, women and children were dragged out and herded into vans. "Those who remained were plundered quite openly of everything in their possessionmoney, jewellery, watches and furs" (301). After some hours, "the trembling survivors found themselves moving off towards Břeclav and safety", every moment "an agony for those who feared to be held up again" (301). Finally, they could see the lights of Břeclav, they had reached the safety of Czechoslovakian territory. The Czech police boarded and announced that all passengers with Austrian passports were to leave the train. The refugees were moved to a guarded waiting room, where they saw from a window that the train they had arrived on was departing for Prague without them. After some hours, Břeclav's Chief of Police came into the waiting room and announced that all Austrian nationals were to be returned to Vienna. As Gedye notes, "one of those who was there and managed by a ruse to escape told me later in Prague that the scenes that followed this announcement were too painful for him to recall" (301). Some of those forcibly returned to Vienna that evening, escaped by departing at Austrian towns en route, taking off on foot into surrounding forests. The rest were returned by train to Vienna, where they were locked in a waiting room at the train station for twelve hours, and were subject to further interrogation by the SS. Some were later 
released, others went "straight to Dachau" (301). By the autumn of 1938, Břeclav was annexed to Nazi Germany. Renamed Lundenburg, its local Jewish population was soon expelled. Its railway station became a node on the transnational train network used to deport Jews to Theresienstadt and extermination camps in Eastern Europe. Over the next few years, refugees halted at Břeclav on 11 March 1938 would return to this border town on special transports - this time their trains travelled straight on through to their final destinations.

\section{Figures}

Figure 1: Břeclav, South Moravia, Czech Republic, 1 September 2015 Igor Zehl/Associated Press CCTK / Alamy Stock Photo, copyright permission obtained.

\section{References}

AFP \& JTA. 2015. “Czech police stop marking refugees with numbers." Times of Israel. 3 September. URL: http://www.timesofisrael.com/numbers-on-refugees-arms-recall-holocaust-jewish-leaders-say/ Ahmed-Čermáková, Martina. 2015. "Strach a hnus v Bělé-Jezové". URL: http://a2larm.cz/2015/09/strach-a-hnus-v-bele-jezove/ Amin, Ash. 2010. "The Remainders of Race." Theory, Culture \& Society. 27 (1): 1-23.

Anon, 2015a. "Czech extremist Adam Bartoš: Put the refugees in a former Nazi concentration camp" URL: http://blisty.cz/art/78865.html

Anon, 2015b. "Minister signals possibility of allowing refugees to cross Czech territory to Germany." URL: http://www.czech.cz/en/Vie-Travail/Minister-signals-possibility-of-allowing-refugees

Back, Les. 2008. "An ordinary virtue." New Jewish Thought. URL:

http://www.newjewishthought.org/AnOrdinaryVirtue.html

Blanden, Adam. 2016. "Central and eastern Europe as playground of a conservative avant-garde." OpenDemocracy. URL: https://www.opendemocracy.net/can-europe-make-it/adamblanden/central-and-eastern-europe-as-playground-of-conservative-avant-garde Biray, Kurt. 2015. "Communist nostalgia in Eastern Europe: longing for the past." OpenDemocracy. URL: https://www.opendemocracy.net/can-europe-make-it/kurt-biray/communist-nostalgia-ineastern-europe-longing-for-past 
Bridgeman, Jon \& Leslie Worley. 2004. "Genocide of the Hereos." 15-51. Century of Genocide: Critical Essays and Eyewitness Accounts. Edited by Samuel Totten, William S. Parsons, Israel W. Charny. New York: Routledge.

Connor, Phillip. 2016. “Number of Refugees to Europe Surges to Record 1.3 Million in 2015." Pew Research Centre. URL: http://www.pewglobal.org/2016/08/02/number-of-refugees-to-europesurges-to-record-1-3-million-in-2015/

Čulík, Jan. 2015. “Prague Springs to Intolerance." POLITICO. August 2. URL: http://www.politico.eu/article/prague-springs-to-intolerance/

Čulík, Jan. 2017. "Why is the Czech Republic So Hostile to Muslims and Refugees?" EuropeNow. URL: http://www.europenowjournal.org/2017/02/09/why-is-the-czech-republic-so-hostile-to-muslimsand-refugees/\#_edn34

Crenshaw, Kimberlé Williams. 2010. "Race, Reform and Retrenchement." in Theories of Race and Racism: A Reader. 549-60. Edited by Les Back and Jon Solomos. London: Routledge.

Dean, Jodi. 2012. The Communist Horizon. London: Verso.

Elias, Ruth. 1999. Triumph of Hope: From Theresienstadt and Auschwitz to Israel. Translated by Margot Bettauer Dembo. New York: John Wiley \& Sons.

Fanon, Frantz. 2005. The Wretched of the Earth. Translated by Richard Philcox. New York: Grove Press.

Flemr, Jan. 2015. "Czech Police spark uproar by tagging refugees with numbers" September 2. Times of Israel. URL: http://www.timesofisrael.com/czech-police-spark-uproar-by-tagging-refugees-withnumbers/

Fields, Barbara and Karen Fields. 2014. Racecraft: The Soul of Inequality in American Life. London: Verso.

Foster, Peter. 2016. “One year ago, Angela Merkel dared to stand up for refugees in Europe. Who else even tried?" The Telegraph. 24 August. URL:

http://www.telegraph.co.uk/news/2016/08/24/one-year-ago-angela-merkel-dared-to-stand-up-forrefugees-in-eur/ 
Frankl, Michal. 2003. "Holocaust Education in the Czech Republic, 1989-2002". Intercultural Education, 14 (2): 177-189.

Gall, Lydia. 2016. “Hungary's War on Refugees” URL:

https://www.hrw.org/news/2016/09/16/hungarys-war-refugees

Gagyi, Agnes, Tamás Gerőcs, Linda Szabó and Márton Szarvas. 2016. “Beyond Moral Interpretations of the EU 'Migration Crisis': Hungary and the Global Economic Division of Labor". LeftEast. URL:

http://www.criticatac.ro/lefteast/beyond-moral-interpretations-of-hu-eu-migration-crisis/

Gedye, George. 1939. Fallen Bastions. The Central European Tragedy. London: Victor Gollancz.

Goffman, Erving. 1987. Stigma: Notes on the Management of Spoiled Identity. New York: Simon \& Schuster.

Gordon, Avery. 1997. Ghostly Matters: Haunting and the Sociological Imagination. Minneapolis: University of Minnesota Press.

Gordon, Avery. 2011. "Some Thoughts on Haunting and Futurity". Borderlands. 10 (2). URL: http://www.borderlands.net.au/vol10no2_2011/gordon_thoughts.pdf

Gustafson, Mark. 2000. "The Tattoo in the Later Roman Empire and Beyond." in Written on the Body: The Tattoo in European and American History. Edited by Jane Caplan. 17-31. Princeton: Princeton University Press.

Hall, Stuart. 1997. 'Race the Floating Signifier." Media Education Foundation. URL: http://www.mediaed.org/transcripts/Stuart-Hall-Race-the-Floating-Signifier-Transcript.pdf Hamm, Patrick, Lawrence King, and David Stuckler. 2012. "Mass privatization, state capacity, and economic growth in postcommunist countries." American Sociological Review. 77(2): 295- 324.

Hrabal, Michal. 2015. "Kdy si ty stany odvezete? ptala se žena na setkání s lidmi z ministerstva" URL: http://breclavsky.denik.cz/zpravy region/kdy-si-ty-stany-odvezete-ptala-se-zena-na-setkani-s-lidmiz-ministerstva-20150908.html

Jones, C.P. 1987. "Stigma: Tattooing and Branding in Graeco-Roman Antiquity." Journal of Roman Studies, 77: 139-155.

URL: http://mc.manuscriptcentral.com/rers ethnic@surrey.ac.uk 
Lentin, Alana. 2016. "Racism in public or public racism: doing anti-racism in 'post-racial' times." Ethnic and Racial Studies, 39(1), 33-48.

Lentin, Alana. 2017. "Learning from Lisa Lowe". URL:

http://www.alanalentin.net/2017/03/03/learning-from-lisa-lowe/

Nowicka, Magdalena. 2017. "'I don't mean to sound racist but ... "' Transforming racism in transnational Europe." Ethnic and Racial Studies, [electronic pre-print].

Olusoga, David \& Casper Erichsen. 2010. The Kaiser's Holocaust. Germany's Forgotten Genocide and the Colonial Roots of Nazism. London: Faber and Faber.

Oxford English Dictionary [online]. 2nd rev. ed. Oxford: Oxford University Press.

Šabatová, Anna. 2015. "Facility for Detention of Foreigners Bělá-Jezová: Evaluation of Systematic Visit" Public Defenders of Rights, Ombudsman. URL:

http://www.ochrance.cz/fileadmin/user_upload/ochrana_osob/ZARIZENI/Zarizeni_pro_cizince/Repo rt_Bela-Jezova.pdf

Sarkin-Hughes, Jeremy. 2010. Germany's Genocide of the Herero: Kasier Wilhelm II, His General, His Settlers, His Soldiers. Cape Town: UCT Press.

Schaller, Dominik. 2013. "The Genocide of the Herero and Nama in German South-West Africa, 1904-1907." in Centuries of Genocide: Essays and Eyewitness Accounts. 89-114. Edited by Samuel Totten and William Parsons. New York: Routledge.

Schultheis, Silla. 2015. "The Refugee Policy of the Visegrád Countries: 'No one invited you'." September 15. URL: https://cz.boell.org/en/2015/09/15/refugee-policy-visegrad-countries-no-oneinvited-you

Sivanandan, A. 2016. Foreword. "Racial Violence in the Brexit State". Institute for Race Relations. URL: http://www.irr.org.uk/app/uploads/2016/11/Racial-violence-and-the-Brexit-state-final.pdf Spillers, Hortense. 2003. Black, White, and in Color: Essays on American Literature and Culture. Chicago: University of Chicago Press.

Tamás, G.M. 2016. "Anti-Immigration Referendum Sunday in Hungary" OpenDemocracy. URL: https://www.opendemocracy.net/can-europe-make-it/g-m-tam-s/anti-immigrationreferendum-sunday-in-hungary 
United Nations. 2015. "Zeid urges Czech Republic to stop detention of migrants and refugees"

October 22. URL:

http://www.ohchr.org/EN/NewsEvents/Pages/DisplayNews.aspx?NewsID=16632\&LangID=E\#sthash. t6NZThkl.dpuf

Weheliye, Alexander. 2014. Habeas Viscus: Racializing Assemblages, Biopolitics, and Black Feminist Theories of the Human. Durham, NC: Duke University Press.

Zelený-Atapana, Mnislav. 2016. “Je na řadě genocida bělochů v Evropě?” Lidovky. URL:

http://www.lidovky.cz/diskuse-je-na-rade-genocida-belochu-v-evrope-fe0-

/nazory.aspx?c=A160718_135549_In_nazory_mct

'The 1990 Dublin Convention updated by the 2003 Dublin II regulation and the 2013 Dublin III regulation, stipulates that asylum applications should ordinarily be processed in the first country of arrival.

ii Established by the Nazis in 1941, Theresienstadt was a Jewish ghetto near Prague and a major departure point for the concentration camps in Eastern Europe.

iii While the turnout for the referendum was under $50 \%$, which made the result legally invalid, $98 \%$ of those who participated voted against the admission of refugees to Hungary, enabling Orbán to claim an ideological victory.

iv As Frankl (2003) details in the Czech context, when the 'final solution' when taught in schools and text books it was remembered as German orchestrated mass killings perpetrated against all citizens, and especially communists, who, it was claimed, had most fiercely resisted fascism.

${ }^{v}$ The yellow star resurrected much older forms of badging Jewish people in Europe, which can be traced back to the $8^{\text {th }}$ century. 